\title{
Effective utilisation of poultry byproduct meal as an ingredient in the diet of Genetically Improved Farmed Tilapia (GIFT), cultured in reservoir cages in Tamil Nadu, South India
}

\author{
N. FELIX ${ }^{1}$, E. PRABU ${ }^{2}$ AND AUROBINDA UPADHYAY ${ }^{3}$ \\ ${ }^{1}$ Directorate of Incubation and Vocational Training in Aquaculture, Tamil Nadu Dr. J. Jayalalithaa Fisheries University \\ ECR-Muttukadu, Chennai - 603 112, Tamil Nadu, India \\ ${ }^{2}$ Dr. M. G. R. Fisheries College and Research Institute, Tamil Nadu Dr. J. Jayalalithaa Fisheries University, Ponneri \\ Chennai - 601 204, Tamil Nadu, India \\ ${ }^{3}$ Fisheries College and Research Institute, Tamil Nadu Dr. J. Jayalalithaa Fisheries University Thoothukudi - 628008 \\ Tamil Nadu, India \\ e-mail: prabufcri@gmail.com
}

\begin{abstract}
Evaluation of efficiency of poultry byproduct meal (PBM) as alternative protein source by replacing fish meal (FM) in the diets of GIFT strain of tilapia (Oreochromis niloticus) was carried out in cages installed in Poondi Reservoir, Tamil Nadu, South India. Six isonitrogenous (30\% protein) and isolipidic (7\% lipid) diets were formulated using graded levels of PBM protein to replace FM protein. Each diet was fed to two replicate groups of GIFT tilapia with mean initial weight of $20.38 \pm 0.0678 \mathrm{~g}$, for 60 days in cages. The best growth performances in terms of mean weight gain $(116.72 \mathrm{~g})$, best food conversion ratio (FCR, 1.14) and maximum hepatosomatic index (HIS, 2.47) values were observed in GIFT tilapia fed PBM diet with $40 \%$ fish meal replacement. However, no significant ( $>0.05$ ) differences were observed in the whole body proximate composition of fish fed control and treatment diets. It was concluded that, poultry byproduct meal can replace $40 \%$ fish meal protein in the diets of GIFT tilapia cultured in reservoir cages without compromising growth, FCR and whole body proximate composition. The study suggests that poultry byproduct meal could effectively replace fish meal without affecting growth and feed conversion of the fish. The findings thus may pave a productive way for reducing environmental pressure of disposal of slaughter house waste.
\end{abstract}

Keywords: Feed ingredient, Fish meal, GIFT tilapia, Poultry byproduct meal, Reservoir cages, Waste utilisation

\section{Introduction}

Global poultry production has increased dramatically in the last 20 years with more than 90 million $t$ of chicken meat and 1.1 trillion eggs now produced every year (FAO, 2018; Blake and Tomley, 2014). At present, India stands fifth in the global poultry meat production. Domestic poultry meat production (broiler-carcass weight) is estimated to have increased from less than 1.0 million $\mathrm{t}$ in 2000 to 3.4 million $\mathrm{t}$ in 2016 (FAO, 2018). The contribution of meat from poultry industry is approximately $36.68 \%$. Slaughtering and processing of poultry birds provide only one third as meat portion while the rest form poultry wastes and byproducts, which need to be effectively processed and utilised. Poultry byproducts include offal, bone, blood, viscera, head, feet and feathers. In India, the total availability of offal/bones, generated from large slaughter houses is estimated to be 21 lakh $\mathrm{t}$ per annum (Jayathilakan et al., 2012). Efficient utilisation of byproducts will have direct impact on the economy and environmental pollution of the country. Non-utilisation or underutilisation of byproducts leads to loss of potential revenue as well as increasing cost of disposal of these products. Non-utilisation of animal byproducts in proper manner may create major aesthetic and catastrophic health problems. In many cases poultry wastes have potential for recycling or for conversion into useful products of higher value.

Nile tilapia (Oreochromis niloticus) is the most farmed tropical fish species in the world (World Bank, 2013). Global production was 5.5 million $\mathrm{t}$ in 2015 (Fitzsimmons, 2016) and is projected to exceed 6.6 million $\mathrm{t}$ by 2030 (FAO, 2018). The attributes which make Nile tilapia so suitable for fish farming are its general hardiness, ease of breeding, rapid growth rate, ability to efficiently convert organic and domestic wastes into high quality protein and good taste (Balarin, 1982). Genetically Improved Farmed Tilapia (GIFT) is known to be a fast growing strain of $O$. niloticus which is widely used in a 
variety of culture systems in Asia (Dey, 2000). Ng and Hanim (2007) concluded that growth was influenced by the interaction between diet and tilapia genotype and feed conversion ratios were 14 and $33 \%$ better in GIFT tilapia compared with red tilapia fed 25 or $35 \%$ protein diet respectively. Supporting the culture of GIFT tilapia in enclosed culture systems like cages would help to boost the global aquaculture sector.

Development of sustainable aquaculture depends on the establishment of alternative feedstuffs to replace fish meal (FM) (Mankinde and Sonaiya, 2012). Animal proteins are free of anti-nutritional factors, palatable, cheaper and readily available than fish meal thus making them perfect FM replacers for tilapia especially in developing nations (El-Sayed, 1999). Poultry byproduct meal (PBM) is made of ground, rendered, or clean parts of the carcass of slaughtered poultry. PBM is similar to FM in composition except being slightly lower in some amino acids (Galkanda-Arachchige et al., 2019). PBM has been tested with varying levels of success so far in salmon (Yang et al., 2004), seabream (Nengas et al., 1999), channel catfish (Sadiku and Jauncey, 1995), tilapia (El-Sayed, 1998) and common carp (Hasan et al., 1997). FM and PBM are highly digestible in terms of protein $(88 \%)$ and energy $(82 \%)$. These digestibility values suggest that PBM could be used in aquafeeds to a level similar to FM (Yang et al., 2004). In this context, the present study was designed to replace fish meal with poultry byproduct meal to develop cost effective feed for GIFT tilapia without affecting the growth performance and feed utilisation.

\section{Materials and methods}

Experimental set-up

The experiment was conducted in Poondi Reservoir in Sathyamurthy Sagar Lake, situated in Poondi Village, Tamil Nadu, India. The reservoir receives water from Kosasthalaiyar River and its total capacity is 3231 million cubic feet. GIFT tilapia seeds were procured from State Fisheries Department, Krishnagiri, Tamil Nadu and were acclimated to the experimental conditions for one month before the start of the experiment. A total of 600 juveniles (mean body weight $20.38 \pm 0.0773 \mathrm{~g}$ ) were uniformly distributed at 50 nos. $\mathrm{m}^{-3}$ in 12 square cages of $1 \times 1 \times 1 \mathrm{~m}$ dimension and were fed on test and reference diets to duplicate groups of fishes.

\section{Experimental diets}

Proximate composition and limiting amino acid content of feed ingredients used are given in Table 1. Ingredient composition of the experimental diets are given in Table 2. Six isonitrogenous (30\% protein) and isolipidic (7\% lipid) experimental diets were formulated including one control diet (OPBM) containing fish meal as main protein source. Other diets were formulated using poultry byproduct meal (PBM) to replace fish meal dietary protein at 20, 40, 60, 80 and 100\% designated as diet 20PBM, 40PBM, 60PBM, 80PBM and 100PBM respectively. The essential amino acid profiles of all the formulated feeds were estimated and the feeds were supplemented with limiting amino acids, lysine and methionine to meet the required levels for Nile tilapia (NRC, 2011). The ingredients were finely ground, blended as per

Table 1. Proximate composition (g $100 \mathrm{~g}^{-1}$ dry matter), gross energy (KJ g $\mathrm{g}^{-1}$ ) and limiting amino acid content (g $100 \mathrm{~g}^{-1}$ protein)

\begin{tabular}{llllll}
\multicolumn{1}{c}{ of ingredients } & & & & \\
\hline Ingredients & Fish meal & Poultry by product meal & Soybean meal & Maize flour & Wheat flour \\
\hline Moisture & 8.96 & 6.20 & 7.63 & 9.80 & 11.74 \\
Protein & 63.28 & 56.75 & 48.70 & 8.29 & 10.05 \\
Lipid & 6.89 & 25.76 & 1.99 & 4.37 & 1.56 \\
Ash & 20.18 & 8.39 & 7.75 & 1.89 & 1.69 \\
Fibre & 0.37 & 1.0 & 7.06 & 2.78 & 1.60 \\
Gross energy $\left(\mathrm{kcal} \mathrm{kg}^{-1}\right)$ & 4254 & 5757 & 4297 & 3907 & 3714 \\
\hline Amino acids $\left({\mathrm{g} 100 \mathrm{~g}^{-1} \text { protein) }}^{\text {Arginine }}\right.$ & 6.2 & 6.6 & & & 4.7 \\
Histidine & 2.4 & 1.8 & 7.4 & 4.5 & 2.3 \\
Isoleucine & 4.2 & 3.9 & 2.6 & 2.8 & 3.4 \\
Leucine & 7.2 & 7.0 & 4.6 & 3.5 & 6.5 \\
Lysine & 7.5 & 4.4 & 7.5 & 3.1 & 2.9 \\
Methionine & 2.7 & 1.4 & 1.4 & 2.1 & 1.6 \\
Phenylalanine & 3.9 & 3.9 & 5.0 & 4.8 & 4.5 \\
Threonine & 4.1 & 3.9 & 3.9 & 3.6 & 2.9 \\
Tryptophan & 1.0 & 0.7 & 1.3 & 0.7 & 4.2 \\
Valine & 4.9 & 5.4 & 4.8 & 4.8 & 4.3 \\
\hline
\end{tabular}


Table 2. Ingredients and proximate composition (\% dry matter basis) of experimental diets

\begin{tabular}{|c|c|c|c|c|c|c|}
\hline Ingredients & 0PBM (Control) & 20PBM & 40PBM & $60 \mathrm{PBM}$ & $80 \mathrm{PBM}$ & 100PBM \\
\hline Fish meal (Anchovy) ${ }^{1}$ & 33 & 26.5 & 20 & 13.2 & 6.63 & 0 \\
\hline Soy bean meal ${ }^{1}$ & 9 & 9.2 & 9.3 & 9.6 & 10 & 10.5 \\
\hline Poultry byproduct meal ${ }^{2}$ & 0 & 7.4 & 14.8 & 22.2 & 29.6 & 37 \\
\hline Maize flour ${ }^{1}$ & 28.49 & 27.90 & 32.82 & 36 & 37.73 & 38.74 \\
\hline Wheat flour ${ }^{1}$ & 23.11 & 22.86 & 17.20 & 13.46 & 10.76 & 8.50 \\
\hline Palm oil ${ }^{1}$ & 2.81 & 2.30 & 1.78 & 1.17 & 0.55 & 0.27 \\
\hline Vitamin premix ${ }^{3}$ & 1 & 1 & 1 & 1 & 1 & 1 \\
\hline Mineral premix ${ }^{4}$ & 1 & 1 & 1 & 1 & 1 & 1 \\
\hline L-Lysine ${ }^{5}$ & 0.44 & 0.60 & 0.80 & 0.98 & 1.26 & 1.34 \\
\hline DL-Methionine $^{6}$ & 1.15 & 1.24 & 1.30 & 1.39 & 1.47 & 1.65 \\
\hline \multicolumn{7}{|c|}{ Proximate composition (\% dry matter basis) } \\
\hline Moisture & 10.77 & 8.69 & 9.88 & 10.06 & 9.70 & 10.02 \\
\hline Protein & 31.40 & 31.91 & 31.69 & 31.64 & 30.06 & 30.49 \\
\hline Lipid & 7.03 & 6.98 & 7.12 & 7.34 & 6.94 & 7.48 \\
\hline Ash & 9.46 & 8.80 & 7.91 & 7.10 & 6.23 & 5.44 \\
\hline Fibre & 1.32 & 1.26 & 1.43 & 1.34 & 1.36 & 1.05 \\
\hline Gross energy $\left(\mathrm{kJ} \mathrm{g}^{-1}\right)$ & 17.31 & 17.94 & 18.03 & 18.20 & 18.47 & 18.70 \\
\hline
\end{tabular}

${ }^{1}$ Hakita Feeds Pvt Ltd., Kodambakkam, Chennai, India

${ }^{2}$ Pragathi Broilers and Farms, Thiruvallur, Tamil Nadu, India

${ }^{3}$ Composition of vitamin premix (quantity kg ${ }^{-1}$ ): Vit. A - 1,00,00,000 IU, Vit. B1-5,000 mg, Vit. B2 - 5,000 mg, Vit. B3- 6,000 mg, Vit. B5 -6,000 mg, Vit. B6 - 6,000 mg, Vit. C - 60,000 mg, Vit. D3 - 20,00,000 IU, Vit. E - 10,000 EU, Vit. H - 200 mg.

${ }^{4}$ Composition of mineral premix (quantity $\mathrm{kg}^{-1}$ ): Magnesium - 2,800 mg, Iodine - 7.4 mg, Iron - 7,400 mg, Copper - 1,200 mg, Manganese - 11,600 mg, Zinc - 9,800 mg, Cobalt chloride - $4 \mathrm{mg}$, Potassium - $100 \mathrm{mg}$, Selenium - $4 \mathrm{mg}$, Calcium carbonate - 27.25\%, Phosphorous - $7.45 \mathrm{mg}$, Sulphur - $0.7 \mathrm{mg}$, Sodium - $6 \mathrm{mg}$, Calpan - $200 \mathrm{mg}$, Aluminium - 1,500 mg and Choline chloride - 10,000 mg

${ }^{5}$ Ajinomoto Heartland, Inc., Chicago (L-lysine HCL - 98.5\%)

${ }^{6}$ Evonik AG, Germany (DL-methionine: MetAMINO ${ }^{\circledast}$ - 99\%)

formulation and passed through a single screw extruder (SFT 65, UNITECH Ltd., New Delhi) to obtain $2 \mathrm{~mm}$ floating pellets. The prepared diets were stored in zip-lock polythene packs in a cool dry place until used.

\section{Feeding trial and fish sampling}

Each diet was fed to two replicate groups of GIFT tilapia juveniles according to the feeding chart given by NFDB (2016), for a period of for 60 days. The feed was given in three split doses daily at 08:00, 10:00 and at $16.00 \mathrm{hrs}$. The fishes were weighed every fortnight and the amount of feed adjusted accordingly. Fishes were harvested on termination of 60 days of feeding trial and length and weight of the fish were recorded. Ten fish from each cage were sampled for whole body proximate analysis.

Proximate analysis of experimental diets and experimental fishes

The moisture, crude protein, lipid, ash, fiber, nitrogen free extract (NFE) and gross energy in the poultry byproduct meal incorporated diets and whole body of the fishes were analysed according to AOAC (1995). Moisture was determined by oven drying at $105-110^{\circ} \mathrm{C}$ for $6 \mathrm{~h}$ and protein by Micro Kjeldhal method after acid digestion. Lipid was determined by Soxhlet's method by extracting in ether which is continuously volatilised at $60-80^{\circ} \mathrm{C}$. Crude fibre was estimated by estimating dried fat free residues after digestion with dilute acid $(0.255 \mathrm{~N})$ and alkali $(0.313 \mathrm{~N})$. Ash was determined by ignition at $600^{\circ} \mathrm{C}$ for $6 \mathrm{~h}$ in a muffle furnace. The gross energy (GE) was estimated using digital bomb calorimeter (Model No. RSB, Rajdhani Scientific Inst. Co., New Delhi, India). The limiting amino acids were analysed after acid hydrolysis with $6 \mathrm{M} \mathrm{HCl}$ using HPLC (Waters Binary Pump 1525). Gross energy was calculated based on conversion factors for carbohydrate, protein and lipid as $17.2 ; 23.6$ and $39.5 \mathrm{~kJ} \mathrm{~g}^{-1}$ respectively.

\section{Survival rate}

Survival rate was calculated at the end of the experiment by counting the number of fishes in each cage and is estimated as follows:

Survival $(\%)=$ Number of fishes harvested/Number of fishes stocked x 100

\section{Growth parameters}

Growth parameters of the experimental fishes were assessed by taking their body weight at the end of the feeding trial. After weighing, GIFT tilapia juveniles were dissected to remove the liver for determination of 
hepatosomatic index (HSI). Moisture was removed with the help of blotting paper and then the liver was weighed $(\mathrm{g})$. Growth was determined by evaluating the following growth and nutrient utilisation indices:

$$
\begin{aligned}
& \text { Mean weight gain } \quad \text { Final body weight - Initial } \\
& (\mathrm{MWG})(\mathrm{g}) \quad=\text { body weight } \\
& \text { Percentage weight }=[\text { (Final body weight }- \text { Initial body } \\
& \text { gain }(\mathrm{PWG})(\%)=\text { weight }) / \text { Initial body weight }] \times 100 \\
& \text { Food conversion }=\text { Total feed consumed }(\mathrm{g}) / \\
& \text { ratio }(\mathrm{FCR}) \quad \text { Wet weight gain }(\mathrm{g}) \\
& \text { Specific growth }=[(\mathrm{Ln} \text { final mean weight }-\mathrm{Ln} \text { initial } \\
& \text { rate }(\mathrm{SGR})(\%) \quad=\quad \text { mean weight }) / \text { number of days }] \times 100 \\
& \text { Protein efficiency }=\text { Wet wet gain }(\mathrm{g}) / \text { Protein } \\
& \text { ratio }(\mathrm{PER}) \quad=\quad \text { ingested }(\mathrm{g}) \\
& \begin{array}{l}
\text { Hepatosomatic } \\
\text { Index (HSI) }
\end{array}=\begin{array}{l}
{[\text { Weight of liver/Weight of the fish }]} \\
\text { x } 100
\end{array}
\end{aligned}
$$

Cage monitoring and water quality parameters

The cages were cleaned regularly to avoid net clogging and to ensure proper water exchange. Fish were monitored regularly to assess the feed intake and health status. Dead fish and leftover feed were removed promptly from the cages. Water quality parameters such as temperature, $\mathrm{pH}$, dissolved oxygen, transparency and conductivity were monitored every 15 days following standard methods (APHA, 2005).

\section{Statistical analysis}

All the data were subjected to one way analysis of variance (ANOVA), which was carried out to find out whether there is any significant difference among the growth related parameters, whereas the Tukey's multiple range test was used to compare treatment means. Statistical analysis was performed using the software SPSS 20.0 for windows (SPSS Inc., Chicago, USA).

\section{Results}

The range of water quality parameters recorded during the feeding trial were, water temperature: $25.5-27^{\circ} \mathrm{C}$, dissolved oxygen: 5.5-6.5 $\mathrm{mg} \mathrm{l}^{-1}$, $\mathrm{pH}$ : 7.5-8.0, Hardness: 120-130 ppm, alkalinity:140-170 ppm, ammonia-N: 0.2-0.4 ppm, nitrite-N: 0.1-0.2 ppm, nitrate-N: 0.06-0.08 ppm.

\section{Survival and growth parameters}

At the end of the 60 days feeding trial, the survival rate $(\%)$ was not significantly different between different treatments (Table 3). Percentage weight gain (PWG) was highest (569.73 g) in GIFT tilapia fed on 40PBM diet, which was significantly different $(p<0.05)$ from the percentage weight gain in fish fed on OPBM, 20PBM, $60 \mathrm{PBM}$ and $80 \mathrm{PBM}$ diets. Lowest percentage weight gain was recorded in the fishes fed with 100PBM, though it was not significantly different $(p>0.05)$ from fishes fed with 60PBM diet.

The highest specific growth rate (SGR) of 3.16 was observed in fish fed on 40PBM diet and lowest SGR (2.18) was recorded in group fed with 100PBM diet. SGR values of 60PBM, 80PBM and 100PBM diets were lower than control diet.

Maximum protein efficiency ratio (PER) was recorded in 40PBM (2.91), followed by OPBM (2.66) and 20PBM (2.79) diet groups. Lowest PER was 100PBM (2.22) followed by 80PBM (2.36) diet groups. GIFT tilapia fed with 40PBM diet showed good food conversion ratio (FCR) of 1.14, followed by OPBM (1.24) and 20PBM (1.19). Poor FCR was observed in 100PBM and 80PBM diet groups. Maximum hepatosomatic Index (HSI) value

\begin{tabular}{|c|c|c|c|c|c|c|c|c|c|}
\hline Treatment & $\begin{array}{l}\text { Mean initial } \\
\text { weight }(\mathrm{g})\end{array}$ & $\begin{array}{l}\text { Mean final } \\
\text { weight }(g)\end{array}$ & $\begin{array}{l}\text { Mean weight } \\
\text { gain }(\mathrm{g})\end{array}$ & PWG & SGR & PER & FCR & HSI & Survival (\%) \\
\hline$\overline{\text { OPBM }}$ & $20.43 \pm 0.85$ & $116.59 \pm 24.4^{\mathrm{d}}$ & $96.16 \pm 23.54^{\mathrm{d}}$ & $470.64 \pm 27.4^{\mathrm{d}}$ & $2.90 \pm 5.57^{\mathrm{c}}$ & $2.66 \pm 5.32^{c}$ & $1.24 \pm 0.62^{\mathrm{b}}$ & $2.34 \pm 0.04^{b}$ & $98 \pm 2.11$ \\
\hline 20PBM & $20.41 \pm 0.91$ & $123.31 \pm 28.6^{\mathrm{e}}$ & $102.90 \pm 27.68^{\mathrm{e}}$ & $504.18 \pm 30.25^{\mathrm{e}}$ & $2.99 \pm 5.73^{\mathrm{bc}}$ & $2.79 \pm 4.16^{\mathrm{c}}$ & $1.19 \pm 0.79^{b}$ & $2.47 \pm 0.07^{\mathrm{d}}$ & $98 \pm 3.1$ \\
\hline 40PBM & $20.48 \pm 0.88$ & $137.21 \pm 22.62^{\mathrm{f}}$ & $116.72 \pm 21.73^{\mathrm{f}}$ & $569.73 \pm 24.43^{\mathrm{f}}$ & $3.16 \pm 5.39^{c}$ & $2.91 \pm 3.47^{\circ}$ & $1.14 \pm 0.95^{\mathrm{a}}$ & $2.36 \pm 0.05^{\mathrm{b}}$ & $98 \pm 3.01$ \\
\hline $60 \mathrm{PBM}$ & $20.35 \pm 0.86$ & $106.31 \pm 30.73^{c}$ & $85.96 \pm 29.86^{c}$ & $422.31 \pm 34.43^{\mathrm{c}}$ & $2.75 \pm 5.94^{\mathrm{bc}}$ & $2.43 \pm 3.74$ & $1.36 \pm 0.89^{c}$ & $2.27 \pm 0.11^{\mathrm{a}}$ & 100 \\
\hline 80PBM & $20.32 \pm 0.86$ & $86.27 \pm 15.84^{b}$ & $65.95 \pm 14.98^{\mathrm{b}}$ & $324.58 \pm 17.27^{b}$ & $2.40 \pm 4.84^{\mathrm{ab}}$ & $2.36 \pm 3.02$ & $1.40 \pm 1.1^{\mathrm{d}}$ & $2.31 \pm 0.04^{b}$ & 100 \\
\hline 100PBM & $20.31 \pm 0.84$ & $75.41 \pm 10.84^{\mathrm{a}}$ & $55.10 \pm 10.01^{\mathrm{a}}$ & $271.31 \pm 11.89^{\mathrm{a}}$ & $2.18 \pm 4.26^{\mathrm{a}}$ & $2.22 \pm 2.17^{\mathrm{a}}$ & $1.49 \pm 1.53^{\circ}$ & $2.40 \pm 0.03^{\mathrm{c}}$ & $98 \pm 3.01$ \\
\hline $\mathrm{p}$ Value & 0.065 & 0.001 & 0.001 & 0.001 & 0.001 & 0.001 & 0.001 & 0.001 & 0.452 \\
\hline
\end{tabular}
of 2.47 was observed in fish fed 20PBM diet compared to other experimental diets.

Initial and final whole body proximate composition

Initial moisture content, crude protein, ether extract and ash content of GIFT tilapia were $71.53 \pm 0.8$, $16.63 \pm 0.6,6.28 \pm 0.3$ and $4.23 \pm 0.2$ respectively (Table 4). No significant differences $(p>0.05)$ were observed in the proximate composition of GIFT tilapia fed control and treatment diets.

Table 3. Growth performances and feed utilisation of GIFT tilapia fed PBM supplemented diets 
Table 4. Whole body proximate composition (\%) of GIFT tilapia juveniles fed experimental diets

\begin{tabular}{llllllll}
\hline Parameter & 0PBM & 20PBM & 40PBM & $60 \mathrm{PBM}$ & 80PBM & 100PBM & $\mathrm{p}$ value \\
\hline Moisture & $68.43 \pm 0.28$ & $68.34 \pm 0.33$ & $68.38 \pm 0.27$ & $68.51 \pm 0.19$ & $68.43 \pm 0.37$ & $68.34 \pm 0.23$ & 0.136 \\
Crude protein & $18.54 \pm 0.17$ & $18.43 \pm 0.15$ & $18.63 \pm 0.09$ & $18.48 \pm 0.21$ & $18.44 \pm 0.14$ & $18.52 \pm 0.16$ & 0.075 \\
Crude lipid & $6.23 \pm 0.07$ & $6.34 \pm 0.11$ & $6.53 \pm 0.13$ & $6.45 \pm 0.05$ & $6.58 \pm 0.17$ & $6.36 \pm 0.14$ & 0.064 \\
Ash & $4.38 \pm 0.06$ & $4.49 \pm 0.03$ & $4.28 \pm 0.07$ & $4.37 \pm 0.03$ & $4.44 \pm 0.01$ & $4.23 \pm 0.05$ & 0.182 \\
\hline
\end{tabular}

Mean value of initial whole body composition: $71.53 \%$ moisture, $16.63 \%$ crude protein, $6.28 \%$ crude lipid and $4.23 \%$ ash

Values are expressed as means $\pm \mathrm{SD}$ of two replicates per treatment $(\mathrm{n}=2)$

\section{Discussion}

Various researchers have studied the effect of substitution of fish meal with different protein sources on the growth, feed utilisation and whole body composition of fishes (El-Saidy and Gaber, 2002; Abdelghany et al., 2003; Borgeson et al, 2006; Gaber, 2006; Hernandez et al., 2010; Figueiredo-Silva et al., 2015). Poultry byproduct meal (PBM) is a rendered product obtained from the waste of poultry production and processing plants. It is usually made from inedible portions of poultry, excluding feathers. It has been evaluated as a fish meal (FM) replacement in the diets of gibel carp Carassius auratus gibelio (Yang et al., 2006), Nile tilapia Oreochromis niloticus (El-Sayed, 1998), African catfish Clarias gariepinus (Abdel-Warith et al., 2001), chinook salmon Oncorhynchus tshawytscha (Fowler, 1991), rainbow trout Oncorhynchus mykiss (Alexis et al., 1985), coho salmon Oncorhynchus kisutch (Higgs et al., 1979), European eel Anguilla anguilla (Gallagher and Degani, 1988), gilthead seabream Sparus aurata (Alexis 1997), red seabream Pagrus major (Takagi et al., 2000), sun shine bass Morone chrysops x M. saxatilis (Webster et al., 1999), red drum Sciaenops ocellatus (Kureshy et al., 2000) and Pacific white shrimp Penaeus vannamei (Davis and Arnold, 2000).

Earlier studies have shown that PBM with $60 \%$ crude protein and 16-22\% ash, if used alone, could generally replace not more than $50 \%$ of FM protein, or growth was compromised (Steffens, 1994). However, an improvement in the nutritional quality of PBM has been achieved in recent years. When supplemented with amino acids (lysine, methionine or tryptophan) or combined with other proteins, PBM showed a more pronounced nutritional potential (Webster et al., 1999). High quality PBM now contains about $70 \%$ crude protein and relatively low ash content (Davis and Arnold 2000) and can even be used without supplementation, replacing $75 \%$ or even $100 \%$ of the FM without a significant depression in fish performance (Alexis 1997; Nengas et al., 1999; Takagi et al., 2000).

In comparison with fish meal, the poultry byproduct meal used in this study had almost equally high protein content (56-60\%), lower ash content, but higher lipid content. Results of the present study indicated that the diets with PBM at 20 and $40 \%$ of the dietary fish meal protein replacements showed higher growth performances compared to control diet (OPBM), which contained only fish meal. Takagi et al. (2000) found that yearling red seabream fed diets with upto 100\% FM replaced by PBM showed a growth performance and feed utilisation similar to or better than fish fed FM-based control diets. Davis and Arnold (2000) reported that replacement of $80 \%$ FM protein in practical diets for $P$. vannamei resulted in a significant increase in weight gain. These varying results may relate to the species tested, but are more likely to be a consequence of the different quality of PBM production, which varies among producers (Dong et al., 1993; Bureau et al., 1999). Dong et al. (1993) found that there were significant differences in proximate composition and protein digestibility in PBM samples obtained from six different manufacturers.

In the present study, with supplementation of required crystal lysine and methionine, growth of GIFT tilapia fed with 20PBM and 40 PBM diets showed similar kind of growth performance as control diet (OPBM) in terms of mean weight gain, PER, FCR, average daily growth and mean feed intake. Fowler (1991) was successful in rearing chinook salmon (Oncorhynchus tschawytscha) with a diet containing 20\% PBM meal without additional amino acid supplementation. Alexis et al. (1985), obtained very good results by feeding rainbow trout, Salmo gairdneri with 20\% PBM meal, with methionine supplementation.

The best FCR values observed with 40PBM diet suggests that replacement of fish meal protein by PBM at $40 \%$ could improve feed utilisation. FCR and PER values were consistent with the values reported in other studies (Fasakin et al., 2005; Prabu et al., 2018). In addition, the results are in agreement with the findings by Hasan et al. (1997), who found that FCR and PER were better at lower substitution levels of FM by hydrolysed feather meal (HFM) in Indian major carp diet. Likewise, FCR and PER decreased significantly with diets containing high levels of HFM in Nile tilapia (Tacon et al., 2008; Davies et al., 1989).

GIFT tilapia fed with PBM incorporated diets showed no significant difference in moisture, protein, lipid and ash 
content in final fish whole body proximate composition among all the treatments. Similar kind of results were observed by Hernandez et al. (2010) where, addition of PBM in Nile tilapia diets did not significantly affect $(\mathrm{p}>0.05)$ carcass crude protein and moisture, however it is contrary to the carcass crude lipid and ash content, which was significantly different among treatments. According to El-Sayed (1998), PBM incorporated fish meal diet caused significant difference in lipid and ash content of Nile tilapia carcass composition. The present study indicated that PBM in the diet of GIFT tilapia could be used as a main protein source to replace fish meal upto $40 \%$ of dietary protein without negative effect on the growth performances and feed utilisation. Optimal replacement of fish meal with PBM in diet for GIFT tilapia requires further investigation with the consideration of essential amino acid requirements.

\section{Acknowledgements}

The authors sincerely thank National Agriculture Development Programme (NADP/RKVY), Tamil Nadu, India and Tamil Nadu Dr. J. Jayalalithaa Fisheries University, Nagapattinam, Tamil Nadu, for the grants and facilities offered.

\section{References}

Abdelghany, A. 2003. Partial and complete replacement of fish meal with gambusia meal in diets for red tilapia 'Oreochromis niloticus $\times$ O. mossambicus'. Aquac. Nutr., 9(3): 145-154. doi.org/10.1046/j.1365-2095.2003.00234.x.

Abdel-Warith, A., Russell, P. and Davies, S. 2001. Inclusion of a commercial poultry byproduct meal as a protein replacement of fish meal in practical diets for African catfish Clarias gariepinus (Burchell 1822). Aquac. Res., 32: 296-305. DOI: 10.1046/j.1355-557x.2001.00053.x.

Alexis, M. 1997. Fish meal and fish oil replacers in Mediterranean marine fish diets. Cah. Options Mediterr., 22: 183-204.

Alexis, M. N., Papaparaskeva-Papoutsoglou, E. and Theochari, V. 1985. Formulation of practical diets for rainbow trout (Salmo gairdneri) made by partial or complete substitution of fish meal by poultry byproducts and certain plant byproducts. Aquaculture, 50(1-2): 61-73.

APHA 2005. Standard methods for the examination of water and waste water, $16^{\text {th }}$ edn. American Public Health Association, Washington D. C., USA, 35 pp.

AOAC 1995. Official method of analysis of water and waste water, $13^{\text {th }}$ edn. Association of Official Analytical Chemists, Washington D.C., USA, 17 pp.

Balarin, J. A., 1982. The intensive culture of tilapia in tanks, raceways and cages. Recent Adv. Aquac., 1: 265-356.

Blake, D. P. and Tomley, F. M. 2014. Securing poultry production from the ever-present Eimeria challenge. Trends Parasitol., 30(1): 12-19. https://doi.org/10.1016/j.pt.2013.10.003.
Borgeson, T., Racz, V., Wilkie, D., White, L. and Drew, M. 2006. Effect of replacing fishmeal and oil with simple or complex mixtures of vegetable ingredients in diets fed to Nile tilapia (Oreochromis niloticus). Aquac.Nutr., 12(2): 141-149. DOI: $10.1111 / j .1365-2095.2006 .00394 . x$.

Bureau, D., Harris, A. and Cho, C. 1999. Apparent digestibility of rendered animal protein ingredients for rainbow trout (Oncorhynchus mykiss). Aquaculture, 180(3-4): 345-358.

Davies, S., Williamson, J., Robinson, M. and Bateson, R. 1989. Practical inclusion levels of common animal byproducts in complete diets for tilapia (Oreochromis mossambicus, Peters), Proceedings of the $3^{\text {rd }}$ International Symposium on feeding and nutrition of fish, Toba, Japan, p. 325-332.

Davis, D. A. and Arnold, C. 2000. Replacement of fish meal in practical diets for the Pacific white shrimp, Litopenaeus vannamei. Aquaculture, 185(3-4): 291-298. DOI: 10.1016/ S0044-8486(99)00354-3.

Dey, M. M. 2000. The impact of genetically improved farmed Nile tilapia in Asia. Aquac. Econ. Manag., 4(1-2): 107-124. https://doi.org/10.1080/13657300009380263.

Dong, F. M., Hardy, R. W., Haard, N. F., Barrows, F. T., Rasco, B. A., Fairgrieve, W. T. and Forster, I. P. 1993. Chemical composition and protein digestibility of poultry byproduct meals for salmonid diets. Aquaculture, 116(2-3): 149-158. http://dx.doi.org/10.1016/0044-8486(93)90005-J.

El-Saidy, D. M. and Gaber, M. M. 2002. Complete replacement of fish meal by soybean meal with dietary L-lysine supplementation for Nile tilapia Oreochromis niloticus (L.) fingerlings. J. World Aquac. Soc., 33(3): 297-306. https:// doi.org/10.1111/j.1749-7345.2002.tb00506.x.

El-Sayed, A. F. 1998. Total replacement of fish meal with animal protein sources in Nile tilapia, Oreochromis niloticus (L.), feeds. Aquac.Res., 29(4): 275-280. https://doi.org/10.1046/ j.1365-2109.1998.00199.x.

El-Sayed, A. F. M. 1999. Alternative dietary protein sources for farmed tilapia, Oreochromis spp. Aquaculture, 179(1-4): 149-168. DOI: 10.1016/S0044-8486(99)00159-3.

Fasakin, E., Serwata, R. and Davies, S. 2005. Comparative utilisation of rendered animal derived products with or without composite mixture of soybean meal in hybrid tilapia (Oreochromis niloticus $\times$ Oreochromis mossambicus $)$ diets. Aquaculture, 249(1-4): 329-338. DOI: 10.1016/j. aquaculture. 2005.02.059.

Figueiredo-Silva, C., Lemme,A., Sangsue, D. and Kiriratnikom, S. 2015. Effect of DL-methionine supplementation on the success of almost total replacement of fish meal with soybean meal in diets for hybrid tilapia (Oreochromis niloticus $\times$ Oreochromis mossambicus). Aquac. Nutr., 21(2): 234-241. https://doi.org/10.1111/anu.12150.

Fitzsimmons, K. 2016. Global tilapia market update 2015. World Aquaculture Society, Las Vegas, Nevada, USA.

FAO 2018. The state of world fisheries and aquaculture 2018: Contributing to food security and nutrition for all. Food and Agriculture Organisation, Rome, Italy. 
Fowler, L. 1991. Poultry byproduct meal as a dietary protein source in fall chinook salmon diets. Aquaculture, 99(3-4): 309-321. DOI: 10.1016/0044-8486(91)90251-2.

Gaber, M. M. 2006. Partial and complete replacement of fish meal by broad bean meal in feeds for Nile tilapia, Oreochromis niloticus, L., fry. Aquac. Res., 37(10): 986-993. https://doi. org/10.1111/j.1365-2109.2006.01517.x.

Gallagher, M. L. and Degani, G. 1988. Poultry meal and poultry oil as sources of protein and lipid in the diet of European eels (Anguilla anguilla). Aquaculture, 73(1-4): 177-187. https://doi.org/10.1016/0044-8486(88)90052-X.

Galkanda-Arachchige, H. S., Wilson, A. E. and Davis, D. A. 2019. Success of fishmeal replacement through poultry byproduct meal in aquaculture feed formulations: a metaanalysis. Rev. Aquac., https://doi.org/10.1111/raq.12401.

Hasan, M., Haq, M., Das, P. and Mowlah, G. 1997. Evaluation of poultry-feather meal as a dietary protein source for Indian major carp, Labeo rohita fry. Aquaculture, 151(1-4): 47-54. https://doi.org/10.1016/S0044-8486(96)01498-6.

Hasan, M., Macintosh, D. and Jauncey, K. 1997. Evaluation of some plant ingredients as dietary protein sources for common carp (Cyprinus carpio L.) fry. Aquaculture, 151(1-4): 55-70. DOI: 10.1016/S0044-8486(96)01499-8.

Hernandez, C., Olvera-Novoa, M., Hardy, R., Hermosillo, A., Reyes, C. and Gonzalez, B. 2010. Complete replacement of fish meal by porcine and poultry byproduct meals in practical diets for fingerling Nile tilapia Oreochromis niloticus: digestibility and growth performance. Aquac. Nutr., 16 (1): 44-53. https://doi.org/10.1111/j.1365-2095. 2008.00639.x.

Higgs, D. A., Markert, J. R., Macquarie, D. W., McBride, J. R., Dosanjh, B. S., Nichols, C. and Hoskins, J. 1979. Development of practical dry diets for coho salmon using poultry byproduct meal, feather meal, soybean meal and rapeseed meal as major protein sources. In: Halver, J. E. and Tiews, K. (Eds.), Finfish nutrition and fishfeed technology. Academic Press, Berlin, Germany, p. 193-207.

Jayathilakan, K., Sultana, K., Radhakrishna, K. and Bawa, A. 2012. Utilisation of byproducts and waste materials from meat, poultry and fish processing industries: a review. J. Food Sci. Technol., 49(3): 278-293. doi: 10.1007/ s13197-011-0290-7.

Kureshy, N., Davis, D. A. and Arnold, C. 2000. Partial replacement of fish meal with meat and bone meal, flash dried poultry byproduct meal and enzyme digested poultry byproduct meal in practical diets for juvenile red drum. North Am. J. Aquac., 62 (4): 266-272. https://doi.org/10.1577/15488454(2000)062<0266:PROFMW> 2.0.CO;2.

Makinde, O. A. and Sonaiya, E. B. 2012. The potential of two vegetable-carried blood meals as protein sources in African catfish (Clarias gariepinus, Burchell) juvenile diets. Open J. Anim. Sci., 2(1): 15-18. DOI:10.4236/ojas.2012.21003.

NFDB 2016. Guidelines for cage culture in inland open water bodies of India. National Fisheries Development Board, Hyderabad, India, 9 pp.

NRC 2011. Nutrient requirements of fish and shrimp. The National Academies Press, Washington, DC, USA.

Nengas, I., Alexis, M. N. and Davies, S. J. 1999. High inclusion levels of poultry meals and related byproducts in diets for gilthead seabream Sparus aurata L. Aquaculture, 179(1-4): 13-23.

Ng, W. K. and Hanim, R. 2007. Performance of genetically improved Nile tilapia compared with red hybrid tilapia fed diets containing two protein levels. Aquac. Res., 38 (9): 965-972. https://doi.org/10.1111/j.1365-2109.2007. 01758.x.

Prabu, E., Rajagopalsamy, C., Ahilan, B., Jeevagan, J. M. A. and Renuhadevi, M. 2018. Effect of dietary supplementation of biofloc meal on growth and survival of GIFT tilapia. Indian J. Fish., 65(1): 65-70.

Sadiku, S. and Jauncey, K. 1995. Digestibility, apparent amino acid availability and waste generation potential of soybean flour: poultry meat meal blend based diets for tilapia, Oreochromis niloticus (L.), fingerlings. Aquac. Res., 26(9): 651-657. DOI: 10.1111/j.1365-2109.1995.tb00956.x.

Steffens, W. 1994. Replacing fish meal with poultry byproduct meal in diets for rainbow trout, Oncorhynchus mykiss. Aquaculture, 124(1-4): 27-34. https://doi.org/10.1016/00 44-8486(94)90351-4.

Tacon, A. G. and Metian, M. 2008. Global overview on the use of fish meal and fish oil in industrially compounded aquafeeds: Trends and future prospects. Aquaculture, 285(1-4): 146158. https://doi.org/10.1016/j.aquaculture.2008.08.015

Takagi, S., Hosokawa, H., Shimeno, S. and Ukawa, M. 2000. Utilisation of poultry byproduct meal in a diet for red sea bream Pagrus major. Nippon Suisan Gakkaishi, 66(3): 428-438.

Takagi, S., Shimeno, S., Hosokawa, H. and Ukawa, M. 2000. Replacement of fish meal by combined inclusion of alternative protein sources in a diet for yearling red seabream, Pagrus major. Aqua. Sci., 48(3): 545-552. https://doi.org/10.11233/aquaculturesci1953.48.545.

Webster, C. D., Tiu, L. G., Morgan, A. M. and Gannam, A. 1999. Effect of partial and total replacement of fish meal on growth and body composition of sunshine bass Morone chrysops $\times$ M. saxatilis fed practical diets. J. World Aquac. Soc., 30(4): 443-453. https://doi.org/10.1111/j.1749-7345.1999. tb00992.x.

World Bank 2013. Fish to 2030: Prospects for fisheries and aquaculture. World Bank Report No. 83177-GLB, 80 pp. 
Yang, Y., Xie, S., Cui, Y., Lei, W., Zhu, X., Yang, Y. and Yu, Y. 2004. Effect of replacement of dietary fish meal by meat and bone meal and poultry byproduct meal on growth and feed utilization of gibel carp, Carassius auratus gibelio. Aquac. Nutr., 10(5): 289-294. https://doi. org/10.1111/j.1365-2095.2004.00301.x.
Yang, Y., Xie, S., Cui, Y., Zhu, X., Lei, W. and Yang, Y. 2006. Partial and total replacement of fishmeal with poultry byproduct meal in diets for gibel carp, Carassius auratus gibelio Bloch. Aquac. Res., 37(1): 40-48. https://doi. org/10.1111/j.1365-2109.2005.01391.x. 